\title{
Sulphur Fractionation Studies in Soils of Long Term Fertilizer Experiment under Finger Millet - Maize Cropping Sequence
}

\author{
K. R. Lavanya ${ }^{1 *}$, G. G. Kadalli ${ }^{1}$, Siddaram Patil ${ }^{1}$, T. Jayanthi ${ }^{1}$, \\ D. V. Naveen ${ }^{2}$ and R. Channabasavegowda ${ }^{1}$ \\ ${ }^{1}$ Department of Soil Science and Agril. Chemistry, College of Agriculture, \\ $U A S, G K V K$, Bengaluru, India \\ ${ }^{2}$ Department of Soil Science and Agril. Chemistry, College of Sericulture, UAS (B), \\ Chintamani, India \\ *Corresponding author
}

\begin{tabular}{l} 
Key w or d s \\
Long term fertilizer, \\
manuring, Sulphur \\
Fractions, \\
Article Info \\
Accepted: \\
$\begin{array}{l}15 \text { August } 2019 \\
\text { Available Online: } \\
\text { 10 September } 2019\end{array}$ \\
\hline
\end{tabular}

\section{A B S T R A C T}

The long term field experiment has been in progress since 1986 at GKVK, Bengaluru with finger millet - hybrid maize cropping sequence. Eleven treatments were replicated four times in RCBD. The archived soil samples $(1986-2016)$ from this experiment were collected at five years interval and studied for different fractions of sulphur. The fractions of sulphur were in the order of organic>residual>inorganic $>$ water soluble> available forms. All fractions of $S$ showed an increasing trend over 30 years of cropping cycles in all the treatments. However, the treatments which did not receive any source of sulphur decreased initially (1991) in all S fractions and then increased gradually over the years and maintained slightly higher over the initial. All forms of $S$ were maintained significantly higher over other treatments and found on par with each other in the treatments receiving $100 \% \mathrm{NPK}+\mathrm{FYM}+$ lime, $100 \% \mathrm{NPK}+\mathrm{FYM}$ and in 150 $\%$ NPK. They found lower in the treatments receiving sulphur free fertilizers (DAP as P source) and imbalanced supply of nutrients. Hence, application of recommended doses of fertilizers (SSP as P source) in combination with FYM is essential in maintaining available sulphur nutrient status and soil health.

\section{Introduction}

Sulphur is one of the seventeen essential elements and the fourth most important nutrient for crop production after nitrogen, phosphorus and potassium. The sulphur deficiency is widespread in Indian soils and it has been emerging as major limitation in increasing crop production and productivity. Intensive cultivation with high yielding varieties of crops and application of high rates of fertilizers devoid of secondary nutrients resulted in depletion of secondary nutrients especially sulphur reserve of soil at faster rate. 
Much of the soil sulphur is present in organic forms in soil. Sulphur is found in several oxidation states which readily undergo transformation by chemical and microbiological processes (Trudinger et al., 1975). Not surprisingly, sulphur in soils occurs in many distinct forms such as water soluble, available, inorganic, organic and total sulphur. The nature and amount of various forms of $\mathrm{S}$ depends on soil texture, $\mathrm{pH}$, calcium carbonate, organic matter and other characteristics (Xiao et al., 2015). The availability of sulphur in a soil is not only influenced by management practices but also depends upon various forms of sulphur present as these different forms of sulphur exist in dynamic equilibrium in soil (Azmi et al., 2018). Hence, the present study was undertaken to assess the status of different forms of sulphur under long term manurial and fertilization experiments.

\section{Materials and Methods}

The long term field experiment has been in progress since 1986 at Zonal Agricultural Research Station of University of Agricultural Sciences, GKVK, Bengaluru located in Eastern Dry Zone of Karnataka with finger millet - hybrid maize cropping sequence. The experiment consists of eleven treatments with four replications in randomized complete block design (RCBD) having individual plot size of $16 \mathrm{~m} \times 9 \mathrm{~m}$. Out of four replications only three replications were selected for this study. Finger millet and hybrid maize crops were grown in sequence during Kharif and Rabi seasons, respectively. The soil of the experimental site is classified as fine, mixed Isothermic Kandic Paleustalfs of Vijayapura series. It is slightly acid with sandy clay loam in texture and sufficient in available sulphur content $\left(20.34 \mathrm{mg} \mathrm{kg}^{-1}\right)$. The physicochemical properties of initial soil sample (1986) of the experimental site are given in table 1 .
The treatments include different levels of NPK, FYM, lime and with and without sulphur source. The treatment details with NPK dosages and fertilizer sources are given in Table 2. Urea, single super phosphate (SSP) and muriate of potash (MOP) were used as sources of $\mathrm{N}, \mathrm{P}$ and $\mathrm{K}$, respectively for all treatments except $\mathrm{S}$ free treatment $\left(\mathrm{T}_{9}\right)$ wherein Di-ammonium phosphate (DAP) was used as a source of P instead of SSP. The 50 $\% \mathrm{~N}$ and $100 \% \mathrm{PK}$ were applied as basal and remaining $50 \% \mathrm{~N}$ was top dressed in two equal splits at 30 and 60 DAS for both finger millet and maize crops. In lime treated plots, the lime $\left(\mathrm{CaCO}_{3}\right)$ was applied based on lime requirement following the method given by Shoemaker et al., (1961) during kharif season. If the $\mathrm{pH}$ is more than 6.00 then lime was applied @200 kg ha ${ }^{-1}$. Farmyard manure (FYM) at the rate of $15 \mathrm{t} \mathrm{ha}^{-1}$ is incorporated into the soil 10-15 days prior to sowing of the kharif crop.

\section{Estimation of sulphur fractions}

The soil samples have been collected from LTFE plots every year after harvest of maize crop since from 1986 to 2016 (30 years). For the present study, these archived soil samples were collected at five years interval (initial1986, 1991, 1996, 2001, 2006, 2011 and 2016) and analysed for different fractions of sulphur by sequential extraction as outlined by Azmi et al., 2018.

\section{Water soluble sulphur}

Five grams of soil was extracted with $25 \mathrm{ml}$ of distilled water (1:5 soil : water ratio) and it was shaken for about 10 minutes, centrifuged and filtered.

\section{Available sulphur}

The soil residue obtained after extraction of water soluble sulphur was treated with $25 \mathrm{ml}$ 
of $1 \% \mathrm{NaCl}$ solution and the content was shaken for half an hour and then centrifuged and filtered.

\section{Inorganic sulphur}

Inorganic sulphur was extracted by adding 25 $\mathrm{ml}$ of $1 \% \mathrm{HCl}$ solution to the soil residue obtained from previous extraction, shaking it for 10 minutes, centrifuged and filtered. The soil was then made chloride free by leaching it with distilled water.

\section{Organic sulphur}

The residue from the $\mathrm{HCl}$ extraction $(2 \mathrm{~g}$ oven dried) was treated with $\mathrm{H}_{2} \mathrm{O}_{2}$ until the effervescence stops, it was centrifuged and filtered.

\section{Total sulphur}

Total sulphur content was determined separately by acid digestion method as per the procedure given by Tabatabai (1982). Five gram of finely ground soil was mixed with 3 ml of 69 per cent $\mathrm{HNO}_{3}$ and heated on steam bath. Then, $3 \mathrm{ml}$ of 60 per cent $\mathrm{HClO}_{4}$ and 7 $\mathrm{ml}$ of $\mathrm{H}_{3} \mathrm{PO}_{4}$ were added and heated on sand bath at $190-210^{\circ} \mathrm{C}$ until white fumes were visible. Two $\mathrm{ml}$ of 37 per cent $\mathrm{HCl}$ was added after cooling and heated again until white fumes visible. The digest was transferred quantitatively and volume was adjusted to $100 \mathrm{ml}$ using $1 \mathrm{~N} \mathrm{HCl}$.

\section{Residual sulphur}

The residual fraction of soil $\mathrm{S}$ represents the unaccounted $S$ not extracted by any of the previous sequential extractants, hence, this fraction was calculated from the difference between total $\mathrm{S}$ and sum of all fractions.

After extraction of different fractions, sulphur in the different extracts was estimated turbidometrically (Chesnin and Yien, 1951). The data collected from experiment were subjected to statistical analysis as described by Gomez and Gomez (1984). The level of significance used in " $F$ " and " $t$ " test was $\mathrm{P}=$ 0.05. Critical difference (CD) values were calculated for the $\mathrm{P}=0.05$ whenever " $\mathrm{F}$ " test was found significant.

\section{Results and Discussion}

Different fractions of sulphur in soil significantly varied due to long term manuring and fertilization over the years at five years interval and the data are presented in tables 3 to 8 and fig. 1.

\section{Water soluble sulphur (WS-S)}

Water soluble sulphur content in soil showed increasing trend over years in all the treatments except in $\mathrm{T}_{9}$ and $\mathrm{T}_{7}$ (Table 3). However, extent of increase was found maximum in $\mathrm{T}_{10}$ (from 11.28 to $31.28 \mathrm{mg} \mathrm{kg}^{-}$ ${ }^{1}$ ) followed by $\mathrm{T}_{8}$ (from 11.26 to $31.24 \mathrm{mg} \mathrm{kg}^{-}$ $\left.{ }^{1}\right)$ which received $F Y M+$ lime in $T_{10}$ and FYM in $\mathrm{T}_{8}$ along with $100 \%$ NPK fertilizer. This indicate that continuous application of FYM along with single super phosphate as $\mathrm{P}$ source increased the WS- S content over years and maintained higher compared to other treatments. This might be due to the release of sulphur from organic source and SSP which is soluble in water. Similarly Scherer et al., (2012) investigated the effect of long-term application of inorganic fertilizers, farmyard manure, compost and sewage sludge and reported that FYM and compost had positive effect as compared to inorganic fertilizer alone on different fractions of sulphur in soil.

Significantly lower water soluble sulphur content in soil was observed over the years in treatment $\mathrm{T}_{9}\left(11.28\right.$ to $\left.8.32 \mathrm{mg} \mathrm{kg}^{-1}\right)$ followed by $\mathrm{T}_{7}$ (11.31 to $\left.9.08 \mathrm{mg} \mathrm{kg}^{-1}\right)$ and $\mathrm{T}_{11}(11.29$ to $15.42 \mathrm{mg} \mathrm{kg}^{-1}$ ) treatments. All these three 
treatments did not receive any $\mathrm{S}$ source indicating continuous cropping without supply of sulphur nutrient decreases the soil sulphur nutrient reserve over the years. Among these three treatments, $\mathrm{T}_{11}$ :Control treatment maintained slightly higher content of water soluble sulphur compared to $\mathrm{T}_{9}$ and $\mathrm{T}_{7}$. This might be due to higher biomass production which in turn resulted in higher uptake of $S$ over the years in $T_{9}$ and $T_{7}$ compared to control $\mathrm{T}_{11}$ treatment.

\section{Available sulphur $\left(\mathrm{SO}_{4}-\mathrm{S}\right.$ or $\left.\mathrm{NaCl}-\mathrm{S}\right)$}

Available sulphur content in soil showed increasing trend over the years in all the treatments except in $\mathrm{T}_{9}, \mathrm{~T}_{7}$ and $\mathrm{T}_{11}$ (Table 4). The extent of increase over years was found maximum in $\mathrm{T}_{10}$ (from 9.06 to $29.24 \mathrm{mg} \mathrm{kg}^{-1}$ ) followed by $\mathrm{T}_{3}$ (from 9.06 to $28.60 \mathrm{mg} \mathrm{kg}^{-1}$ ) which received $100 \% \mathrm{NPK}+\mathrm{FYM}+$ lime and $150 \%$ NPK, respectively. And these two treatments recorded significantly higher available sulphur content compared to other treatments indicating continuous application of higher dose of S through SSP or $100 \%$ RDF (SSP as P source) in combination with FYM helped in buildup of $\mathrm{SO}_{4}-\mathrm{S}$ in the soil over the years. The results of present study are also in conformity with the findings of Setia and Sharma (2005) who have recorded higher available sulphur content in the long term fertilized soils under maize-wheat cropping system in treatment which received higher amount of single superphosphate. Similar results were also reported by Sharma and Jaggi (2001), Bhatnagar et al., (2003) and Mazur and Mazur (2015). Nguyen and Goh (1990) reported that in the soils receiving long term super phosphate, $\mathrm{CaCl}_{2}$ - extractable soil $S$ increased over the years of pasture development, but the rate of increase decreased with time.
Like WS-S, the available sulphur content was also recorded significantly lower in treatments with continuous application sulphur free phosphatic fertilizer (DAP) $\left(\mathrm{T}_{9}\right)$ and treatment with only 100 per cent $\mathrm{N}\left(\mathrm{T}_{7}\right)$ and in control $\left(\mathrm{T}_{11}\right)$. In these treatments, there was decrease in available $S$ content initially (1991) and then increased gradually over the years and maintained slightly higher over the initial soil $S$ content. Decrease in the available $S$ content initially was due to higher removal of native sulphur by the crop as the biomass production was reported to be higher initially (Anon, 1992). Later gradual build up was due to lower biomass production and in turn lower uptake of native $S$ compared to the rate of $S$ mineralization from the soil (Anon, 2017). Sahoo et al., (1998) reported that continuous cultivation of crops without addition of plant nutrients had decreased the available sulphur in the soil due to crop removal of native sulphur.

\section{Inorganic sulphur (HCl-S)}

The amount of inorganic sulphur in soil showed increasing trend over the years in all the treatments. However, in $\mathrm{T}_{9}, \mathrm{~T}_{7}$ and $\mathrm{T}_{11}$ treatments, there was decrease in inorganic $\mathrm{S}$ content initially (1991) and then increased gradually over the years and maintained slightly higher over the initial soil S content (Table 5). The extent of increase over 30 years was found maximum in $\mathrm{T}_{3}$ (from 15.72 to $35.42 \mathrm{mg} \mathrm{kg}^{-1}$ ) followed by $\mathrm{T}_{10}$ (from 15.76 to $34.82 \mathrm{mg} \mathrm{kg}^{-1}$ ) which received $150 \%$ NPK and $100 \%$ NPK + FYM + lime, respectively. This fraction also found significantly higher in these treatments compared to other treatments indicating continuous application of higher dose of S through SSP or $100 \%$ RDF (SSP as $\mathrm{P}$ source) in combination with FYM helped in buildup of $\mathrm{HCl}-\mathrm{S}$ in the soil over the years. 
Table.1 Initial physico-chemical properties of initial soil sample of study site (1986)

\begin{tabular}{|c|c|c|}
\hline Sl. No. & Soil property & Value \\
\hline \multirow[t]{5}{*}{1} & Particle size analysis & \\
\hline & a. Sand $(\%)$ & 62.00 \\
\hline & b. Silt (\%) & 8.60 \\
\hline & c. Clay (\%) & 29.40 \\
\hline & Soil textural class & Sandy clay loam \\
\hline 2 & Bulk Density $\left(\mathrm{Mg} \mathrm{kg}^{-1}\right)$ & 1.51 \\
\hline 3 & $\mathrm{pH}$ (1:2.5 soil:water suspension) & 6.17 \\
\hline 4 & Electrical conductivity $\left(\mathrm{dS} \mathrm{m}^{-1}\right)$ & 0.059 \\
\hline 5 & Organic carbon $(\%)$ & 0.60 \\
\hline 6 & Cation exchange capacity $\left[\mathrm{c} \mathrm{mol}\left(\mathrm{p}_{+}\right) \mathrm{kg}^{-1}\right]$ & 12.20 \\
\hline 7 & Available nitrogen $\left(\mathrm{kg} \mathrm{N} \mathrm{ha}^{-1}\right)$ & 256.70 \\
\hline 8 & Available phosphorus $\left(\mathrm{kg} \mathrm{P}_{2} \mathrm{O}_{5} \mathrm{ha}^{-1}\right)$ & 34.30 \\
\hline 9 & Available potassium $\left(\mathrm{kg} \mathrm{K}_{2} \mathrm{O} \mathrm{ha}^{-1}\right)$ & 123.10 \\
\hline 10 & Available sulphur $\left(\mathrm{mg} \mathrm{kg}^{-1}\right)$ & 20.34 \\
\hline 11 & Exchangeable calcium $\left[\mathrm{c} \mathrm{mol}\left(\mathrm{p}+\mathrm{kg}^{-1}\right]\right.$ & 3.25 \\
\hline 12 & Exchangeable magnesium $\left[\mathrm{c} \mathrm{mol}(\mathrm{p}+)^{-1} \mathrm{~kg}^{-1}\right]$ & 1.55 \\
\hline
\end{tabular}

Table.2 Treatments details of long term fertilizer experiment

\begin{tabular}{|c|c|c|c|}
\hline \multirow[t]{2}{*}{ Treatments } & \multicolumn{2}{|c|}{ NPK dosage $\left(\mathrm{kg} \mathrm{ha}^{-1}\right)$} & \multirow[t]{2}{*}{ Fertilizer source } \\
\hline & Finger millet & Hybrid maize & \\
\hline$T_{1}: 50 \%$ NPK & $50-11-21$ & $50-16-41$ & Urea, SSP, MOP \\
\hline$T_{2}: 100 \%$ NPK & $100-22-42$ & $100-32-82$ & Urea, SSP, MOP \\
\hline$T_{3}: 150 \%$ NPK & $150-33-63$ & $150-48-123$ & Urea, SSP, MOP \\
\hline $\mathbf{T}_{4}: 100 \% \mathrm{NPK}+$ Hand Weeding & $100-22-42$ & $100-32-82$ & Urea, SSP, MOP \\
\hline$T_{5}: 100 \% \mathrm{NPK}+$ lime & $100-22-42$ & $100-32-82$ & Urea, SSP, MOP, lime \\
\hline $\mathrm{T}_{6}: 100 \% \mathrm{NP}$ & $100-22-00$ & $100-32-00$ & Urea, SSP \\
\hline$T_{7}: 100 \% \mathrm{~N}$ & $100-00-00$ & $100-00-00$ & Urea \\
\hline $\mathrm{T}_{8}: 100 \% \mathrm{NPK}+\mathrm{FYM}$ & $100-22-42$ & $100-32-82$ & Urea, SSP, MOP \\
\hline$T_{9}: 100 \%$ NPK (S-free) & $100-22-42$ & $100-32-82$ & Urea, DAP, MOP \\
\hline $\mathrm{T}_{10}: 100 \% \mathrm{NPK}+\mathrm{FYM}$ + lime & $100-22-42$ & $100-32-82$ & Urea, SSP, MOP, lime \\
\hline $\mathbf{T}_{11}:$ Control & $00-00-00$ & $00-00-00$ & ……...... \\
\hline
\end{tabular}

Note: Chemical weeding was followed in all treatments except $\mathrm{T}_{4}$ 
Table.3 Effect of long term manuring on water soluble sulphur content in soil over the years from 1986 to 2016 at five years interval.

\begin{tabular}{|c|c|c|c|c|c|c|c|}
\hline \multirow[t]{2}{*}{ Treatments } & 1986 & 1991 & 1996 & 2001 & 2006 & 2011 & 2016 \\
\hline & \multicolumn{7}{|c|}{$\mathrm{mg} \mathrm{kg}^{-1}$} \\
\hline$T_{1}: 50 \%$ NPK & 11.28 & 13.82 & 15.12 & 16.84 & 17.67 & 18.67 & 20.36 \\
\hline$T_{2}: 100 \%$ NPK & 11.24 & 21.34 & 23.62 & 25.12 & 26.12 & 28.63 & 27.02 \\
\hline$T_{3}: 150 \%$ NPK & 11.30 & 24.86 & 25.32 & 27.84 & 28.34 & 31.06 & 30.24 \\
\hline $\mathrm{T}_{4}: 100 \% \mathrm{NPK}+\mathrm{HW}$ & 11.26 & 21.67 & 23.16 & 25.62 & 26.42 & 27.04 & 26.12 \\
\hline$T_{5}: 100 \%$ NPK + lime & 11.27 & 23.35 & 24.54 & 27.42 & 28.94 & 29.43 & 29.85 \\
\hline$T_{6}: 100 \% \mathrm{NP}$ & 11.28 & 19.81 & 21.18 & 23.06 & 24.82 & 28.72 & 27.24 \\
\hline$T_{7}: 100 \% \mathrm{~N}$ & 11.31 & 7.73 & 8.02 & 8.48 & 8.82 & 9.29 & 9.08 \\
\hline $\mathrm{T}_{8}: 100 \% \mathrm{NPK}+\mathrm{FYM}$ & 11.26 & 25.20 & 26.68 & 30.52 & 30.74 & 31.96 & 31.24 \\
\hline$T_{9}: 100 \%$ NPK (S-free) & 11.28 & 6.86 & 7.24 & 7.68 & 8.26 & 8.74 & 8.32 \\
\hline$T_{10}: 100 \%$ NPK + FYM + lime & 11.28 & 25.38 & 26.87 & 28.92 & 31.48 & 33.87 & 31.28 \\
\hline $\mathbf{T}_{11}$ : Control & 11.29 & 11.68 & 12.62 & 13.78 & 14.24 & 16.37 & 15.42 \\
\hline SEm \pm & 0.40 & 0.67 & 0.71 & 0.78 & 0.82 & 0.88 & 0.86 \\
\hline CD@ $5 \%$ & NS & 198 & 2.10 & 2.31 & 2.43 & 2.59 & 2.52 \\
\hline
\end{tabular}

Table.4 Effect of long term manuring on available sulphur content in soil over the years from 1986 to 2016 at five years interval

\begin{tabular}{|c|c|c|c|c|c|c|c|}
\hline \multirow[t]{2}{*}{ Treatments } & 1986 & 1991 & 1996 & 2001 & 2006 & 2011 & 2016 \\
\hline & \multicolumn{7}{|c|}{$\mathrm{mg} \mathrm{kg}^{-1}$} \\
\hline $\mathrm{T}_{1}: 50 \% \mathrm{NPK}$ & 9.08 & 11.26 & 13.34 & 15.14 & 16.25 & 17.85 & 20.29 \\
\hline$T_{2}: 100 \%$ NPK & 9.11 & 15.24 & 17.42 & 21.31 & 20.31 & 22.46 & 22.50 \\
\hline$T_{3}: 150 \%$ NPK & 9.06 & 20.82 & 22.86 & 26.78 & 25.53 & 31.92 & 28.60 \\
\hline $\mathrm{T}_{4}: 100 \% \mathrm{NPK}+\mathrm{HW}$ & 9.05 & 16.78 & 18.21 & 22.33 & 23.25 & 24.57 & 22.21 \\
\hline$T_{5}: 100 \% \mathrm{NPK}+$ lime & 9.12 & 18.24 & 20.84 & 24.83 & 24.86 & 21.04 & 25.31 \\
\hline $\mathrm{T}_{6}: 100 \% \mathrm{NP}$ & 9.08 & 20.68 & 21.78 & 25.89 & 28.46 & 22.14 & 23.92 \\
\hline $\mathrm{T}_{7}: 100 \% \mathrm{~N}$ & 9.15 & 6.12 & 6.86 & 7.58 & 7.63 & 13.16 & 10.13 \\
\hline $\mathrm{T}_{8}: 100 \% \mathrm{NPK}+\mathrm{FYM}$ & 9.06 & 16.82 & 18.54 & 22.72 & 25.44 & 24.32 & 27.88 \\
\hline$T_{9}: 100 \%$ NPK (S-free) & 9.11 & 5.98 & 6.12 & 6.34 & 7.32 & 9.92 & 9.83 \\
\hline $\mathrm{T}_{10}: \mathbf{1 0 0} \% \mathrm{NPK}+\mathrm{FYM}+$ lime & 9.06 & 19.72 & 22.12 & 26.39 & 28.83 & 29.14 & 29.24 \\
\hline $\mathbf{T}_{11}:$ Control & 9.08 & 6.58 & 6.32 & 6.79 & 8.25 & 10.41 & 11.85 \\
\hline SEm \pm & 0.007 & 0.54 & 0.59 & 0.70 & 0.74 & 0.64 & 0.78 \\
\hline CD @ $5 \%$ & NS & 1.58 & 1.75 & 2.07 & 2.17 & 1.89 & 2.29 \\
\hline
\end{tabular}


Table.5 Effect of long term manuring on inorganic sulphur content in soil over the years from 1986 to 2016 at five years interval

\begin{tabular}{|c|c|c|c|c|c|c|c|}
\hline \multirow[t]{2}{*}{ Treatments } & 1986 & 1991 & 1996 & 2001 & 2006 & 2011 & 2016 \\
\hline & \multicolumn{7}{|c|}{$\mathrm{mg} \mathrm{kg}^{-1}$} \\
\hline $\mathrm{T}_{1}: \mathbf{5 0} \% \mathrm{NPK}$ & 15.71 & 18.42 & 20.18 & 22.64 & 24.82 & 25.16 & 25.86 \\
\hline $\mathrm{T}_{2}: 100 \% \mathrm{NPK}$ & 15.76 & 23.82 & 26.18 & 29.24 & 29.86 & 30.92 & 31.84 \\
\hline $\mathrm{T}_{3}: 150 \% \mathrm{NPK}$ & 15.72 & 28.82 & 31.86 & 32.84 & 33.12 & 33.86 & 35.42 \\
\hline $\mathrm{T}_{4}: 100 \% \mathrm{NPK}+\mathrm{HW}$ & 15.69 & 23.12 & 25.62 & 28.86 & 29.12 & 30.52 & 31.76 \\
\hline $\mathrm{T}_{5}: 100 \% \mathrm{NPK}+$ lime & 15.74 & 26.12 & 27.86 & 28.24 & 30.46 & 31.68 & 34.72 \\
\hline $\mathrm{T}_{6}: 100 \% \mathrm{NP}$ & 15.73 & 22.14 & 26.24 & 27.08 & 27.74 & 28.12 & 32.78 \\
\hline $\mathrm{T}_{7}: 100 \% \mathrm{~N}$ & 15.72 & 15.89 & 16.28 & 16.68 & 17.02 & 17.83 & 18.28 \\
\hline $\mathrm{T}_{8}: 100 \% \mathrm{NPK}+\mathrm{FYM}$ & 15.77 & 26.86 & 29.24 & 29.74 & 31.54 & 32.68 & 33.49 \\
\hline$T_{9}: 100 \%$ NPK (S-free) & 15.75 & 15.22 & 15.64 & 16.27 & 16.34 & 16.88 & 17.32 \\
\hline $\mathrm{T}_{10}: 100 \% \mathrm{NPK}+\mathrm{FYM}$ + lime & 15.76 & 27.12 & 30.72 & 31.14 & 32.86 & 33.08 & 34.82 \\
\hline $\mathbf{T}_{11}:$ Control & 15.76 & 16.84 & 17.28 & 17.87 & 18.34 & 18.76 & 19.68 \\
\hline SEm \pm & 0.55 & 0.79 & 0.87 & 0.90 & 0.94 & 0.97 & 1.02 \\
\hline CD@ $5 \%$ & NS & 2.34 & 2.56 & 2.65 & 2.78 & 2.85 & 3.02 \\
\hline
\end{tabular}

Table.6 Effect of long term manuring on organic sulphur content in soil over the years from 1986 to 2016 at five years interval

\begin{tabular}{|c|c|c|c|c|c|c|c|}
\hline \multirow[t]{2}{*}{ Treatments } & 1986 & 1991 & 1996 & 2001 & 2006 & 2011 & 2016 \\
\hline & \multicolumn{7}{|c|}{$\mathrm{mg} \mathrm{kg}^{-1}$} \\
\hline $\mathrm{T}_{1}: \mathbf{5 0} \% \mathrm{NPK}$ & 212.63 & 216.07 & 228.27 & 220.00 & 222.43 & 223.97 & 228.02 \\
\hline $\mathrm{T}_{2}: 100 \% \mathrm{NPK}$ & 212.78 & 218.09 & 217.82 & 224.17 & 226.60 & 228.62 & 229.64 \\
\hline $\mathrm{T}_{3}: 150 \% \mathrm{NPK}$ & 213.84 & 220.52 & 228.90 & 225.18 & 227.61 & 230.24 & 233.69 \\
\hline $\mathrm{T}_{4}: 100 \% \mathrm{NPK}+\mathrm{HW}$ & 212.42 & 219.00 & 220.82 & 224.37 & 227.41 & 229.64 & 231.05 \\
\hline $\mathrm{T}_{5}: 100 \% \mathrm{NPK}$ + lime & 214.85 & 220.22 & 226.57 & 225.38 & 226.60 & 229.35 & 232.07 \\
\hline $\mathrm{T}_{6}: 100 \% \mathrm{NP}$ & 211.41 & 216.88 & 216.38 & 222.55 & 224.17 & 227.31 & 230.45 \\
\hline $\mathrm{T}_{7}: 100 \% \mathrm{~N}$ & 212.22 & 214.04 & 211.62 & 219.31 & 220.93 & 222.55 & 222.95 \\
\hline $\mathrm{T}_{8}: 100 \% \mathrm{NPK}+\mathrm{FYM}$ & 213.03 & 220.93 & 232.75 & 239.07 & 240.65 & 245.17 & 246.37 \\
\hline$T_{9}: 100 \%$ NPK (S-free) & 213.74 & 211.01 & 209.64 & 215.16 & 216.47 & 218.30 & 219.92 \\
\hline $\mathrm{T}_{10}: 100 \% \mathrm{NPK}+\mathrm{FYM}$ + lime & 213.19 & 221.33 & 234.64 & 239.82 & 239.31 & 241.90 & 244.91 \\
\hline $\mathbf{T}_{11}:$ Control & 213.51 & 214.93 & 217.84 & 219.41 & 220.52 & 222.47 & 223.97 \\
\hline SEm \pm & 7.49 & 7.64 & 7.44 & 6.82 & 6.83 & 6.94 & 6.94 \\
\hline CD@ $@ 5 \%$ & NS & NS & 21.95 & 20.13 & 20.15 & 20.48 & 20.47 \\
\hline
\end{tabular}


Table.7 Effect of long term manuring on residual sulphur content in soil over the years from 1986 to 2016 at five years interval

\begin{tabular}{|c|c|c|c|c|c|c|c|}
\hline \multirow[t]{2}{*}{ Treatments } & 1986 & 1991 & 1996 & 2001 & 2006 & 2011 & 2016 \\
\hline & \multicolumn{7}{|c|}{$\mathrm{mg} \mathrm{kg}^{-1}$} \\
\hline $\mathbf{T}_{1}: 50 \% \mathrm{NPK}$ & 33.95 & 34.86 & 35.68 & 37.82 & 39.78 & 42.37 & 43.18 \\
\hline $\mathrm{T}_{2}: 100 \% \mathrm{NPK}$ & 33.92 & 36.24 & 37.28 & 38.42 & 39.06 & 40.24 & 42.78 \\
\hline $\mathrm{T}_{3}: 150 \% \mathrm{NPK}$ & 33.88 & 37.54 & 38.24 & 39.38 & 41.28 & 43.74 & 45.68 \\
\hline $\mathrm{T}_{4}: 100 \% \mathrm{NPK}+\mathrm{HW}$ & 33.96 & 36.52 & 37.34 & 38.68 & 39.72 & 40.62 & 42.53 \\
\hline $\mathrm{T}_{5}: 100 \% \mathrm{NPK}+$ lime & 34.02 & 36.78 & 43.23 & 38.37 & 39.87 & 41.28 & 43.78 \\
\hline $\mathrm{T}_{6}: 100 \% \mathrm{NP}$ & 33.95 & 35.24 & 37.12 & 38.48 & 39.11 & 39.48 & 42.16 \\
\hline $\mathrm{T}_{7}: 100 \% \mathrm{~N}$ & 33.98 & 33.12 & 33.67 & 33.99 & 34.77 & 35.12 & 35.68 \\
\hline $\mathrm{T}_{8}: 100 \% \mathrm{NPK}+\mathrm{FYM}$ & 33.94 & 37.22 & 39.43 & 40.13 & 39.27 & 41.4 & 43.84 \\
\hline$T_{9}: 100 \%$ NPK (S-free) & 33.96 & 31.74 & 32.68 & 33.12 & 33.64 & 34.28 & 34.72 \\
\hline $\mathrm{T}_{10}: 100 \% \mathrm{NPK}+\mathrm{FYM}+$ lime & 33.98 & 36.47 & 35.5 & 37.12 & 39.39 & 42.54 & 43.79 \\
\hline $\mathbf{T}_{11}:$ Control & 33.98 & 33.16 & 33.6 & 34.16 & 34.74 & 35.62 & 36.38 \\
\hline SEm \pm & 1.192 & 1.238 & 1.274 & 1.303 & 1.344 & 1.402 & 1.455 \\
\hline CD@ $@ 5 \%$ & NS & 3.65 & 3.76 & 3.84 & 3.96 & 4.14 & 4.29 \\
\hline
\end{tabular}

Table.8 Effect of long term manuring on total sulphur content in soil over the years from 1986 to 2016 at five years interval

\begin{tabular}{|c|c|c|c|c|c|c|c|}
\hline \multirow[t]{2}{*}{ Treatments } & 1986 & 1991 & 1996 & 2001 & 2006 & 2011 & 2016 \\
\hline & \multicolumn{7}{|c|}{$\mathrm{mg} \mathrm{kg}^{-1}$} \\
\hline $\mathrm{T}_{1}: 50 \% \mathrm{NPK}$ & 273.69 & 294.43 & 312.59 & 312.44 & 320.95 & 328.02 & 337.71 \\
\hline $\mathrm{T}_{2}: 100 \% \mathrm{NPK}$ & 285.88 & 314.73 & 322.32 & 338.26 & 341.95 & 350.87 & 353.78 \\
\hline $\mathrm{T}_{3}: 150 \% \mathrm{NPK}$ & 277.11 & 332.56 & 347.18 & 352.02 & 355.88 & 370.82 & 373.63 \\
\hline$T_{4}: 100 \% \mathrm{NPK}+\mathrm{HW}$ & 282.10 & 317.09 & 325.15 & 339.86 & 345.92 & 352.39 & 353.67 \\
\hline$T_{5}: 100 \%$ NPK + lime & 271.05 & 324.71 & 343.04 & 344.24 & 350.73 & 352.78 & 365.73 \\
\hline $\mathrm{T}_{6}: 100 \% \mathrm{NP}$ & 286.01 & 314.75 & 322.70 & 337.06 & 344.30 & 345.77 & 356.55 \\
\hline $\mathbf{T}_{7}: 100 \% \mathrm{~N}$ & 287.17 & 276.90 & 276.45 & 286.04 & 289.17 & 297.95 & 296.12 \\
\hline $\mathrm{T}_{8}: 100 \% \mathrm{NPK}+\mathrm{FYM}$ & 275.30 & 327.03 & 346.64 & 362.18 & 367.64 & 375.53 & 382.82 \\
\hline$T_{9}: 100 \%$ NPK (S-free) & 286.33 & 270.81 & 271.32 & 278.67 & 282.03 & 288.12 & 290.11 \\
\hline $\mathrm{T}_{10}: 100 \% \mathrm{NPK}+\mathrm{FYM}$ + lime & 289.40 & 330.02 & 334.85 & 363.39 & 371.89 & 375.53 & 384.04 \\
\hline $\mathbf{T}_{11}:$ Control & 273.78 & 283.19 & 296.66 & 292.01 & 296.09 & 303.63 & 307.30 \\
\hline SEm \pm & 9.81 & 10.80 & 11.20 & 10.81 & 9.82 & 12.66 & 11.67 \\
\hline CD@ $@ 5 \%$ & NS & 31.85 & 33.04 & 31.90 & 28.96 & 37.36 & 34.42 \\
\hline
\end{tabular}


Fig.1 Effect of long term manuring on different sulphur fractions content in soil over the years from 1986 to 2016 at five years interval.
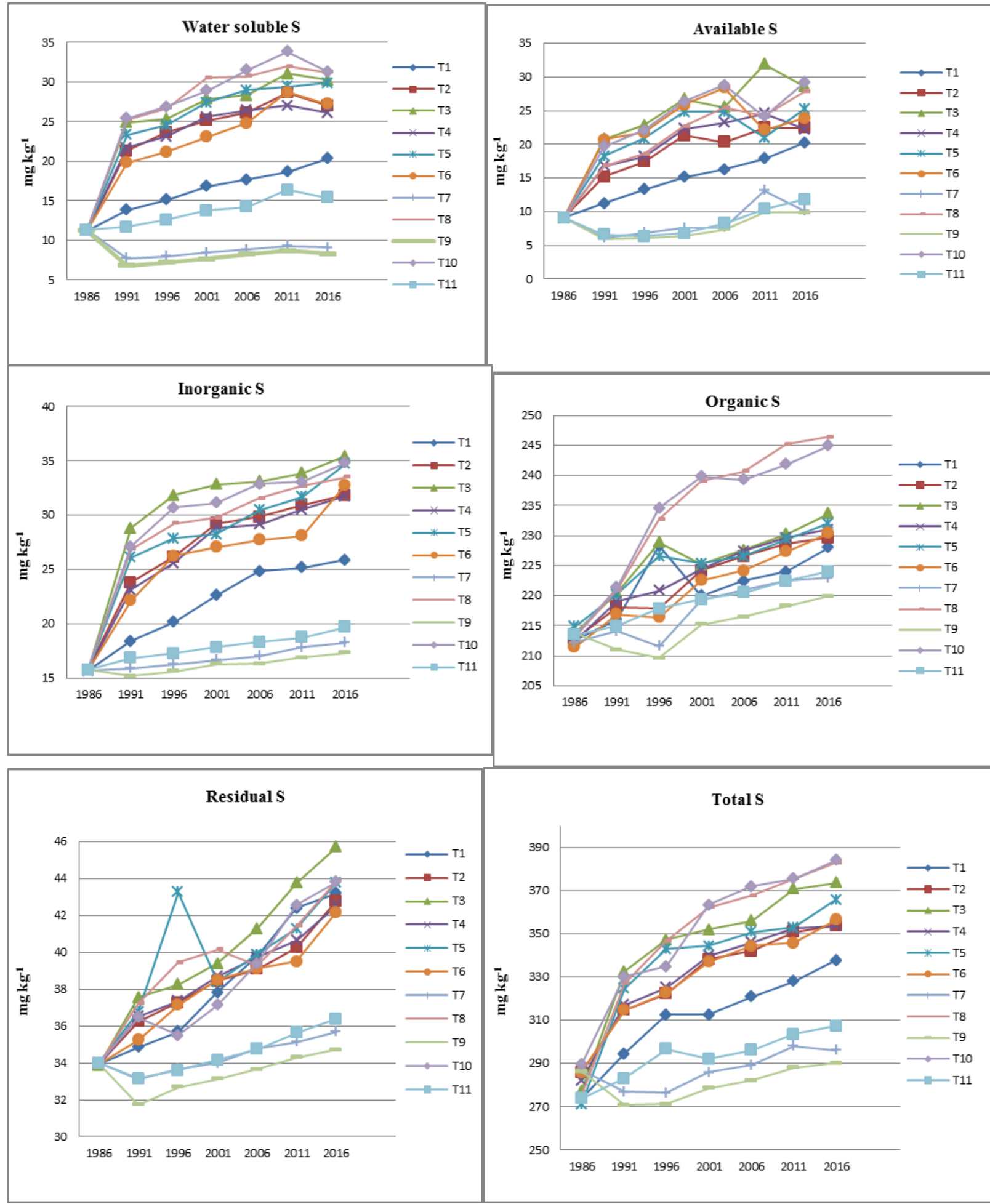
Increase in inorganic sulphur content was found to be minimum in treatment $\mathrm{T}_{9}(15.75$ to $17.32 \mathrm{mg} \mathrm{kg}^{-1}$ ) which received $\mathrm{S}$ free phosphatic fertilizer (DAP) followed by $\mathrm{T}_{7}$ (15.72 to $18.28 \mathrm{mg} \mathrm{kg}^{-1}$ ) which received only $100 \% \mathrm{~N}$ and control (15.76 to $19.68 \mathrm{mg} \mathrm{kg}^{-1}$ ). Addition of only nitrogenous fertilizer to soil favoured solubilisation of the sulphate that was co-precipitated with $\mathrm{CaCO}_{3}$ and the solubilized sulphate was partly transformed into soluble organic form ( $\mathrm{Hu}$ et al., 2005).The results were in conformity with the observations recorded by Sharma et al., (2014), who showed that zero fertilization led to decline in the levels of all $\mathrm{S}$ forms, while application of sulphur containing fertilizer and organics increased it over control. This might be due to release of sulphur from inorganic and organic $\mathrm{S}$ sources applied to different treatments and the treatments which recorded lower inorganic sulphur was due to continuous crop removal without addition of any $\mathrm{S}$ source and conversion of inorganic form of sulphur to sulphate sulphur.

\section{Organic sulphur in soil}

The data in table 6 indicates that organic $S$ was the major fraction of $S$ in soil whose extent and distribution was further increased with continuous use of S through SSP and FYM organic manure. Organic sulphur content in soil showed increasing trend over 30 years in all the treatments. The extent of increase over the years was found maximum in $\mathrm{T}_{8}$ (from 213.03 to $246.37 \mathrm{mg} \mathrm{kg}^{-1}$ ) followed by $\mathrm{T}_{10}$ (from 213.19 to $244.91 \mathrm{mg} \mathrm{kg}^{-1}$ ) which received both FYM and $100 \%$ NPK indicating the distribution of organic sulphur in these soils is mainly influenced by the organic matter treatment. The results were in conformity with the observations recorded by Jat and Yadav (2006).

Organic sulphur content was significantly lower and increase was minimum over the years in the treatment $\mathrm{T}_{9}(213.74$ to $219.92 \mathrm{mg}$ $\mathrm{kg}^{-1}$ ) which received $\mathrm{S}$ free $\mathrm{P}$ fertilizer (DAP) followed by $\mathrm{T}_{7}$ (212.22 to $222.95 \mathrm{mg} \mathrm{kg}^{-1}$ ) which received only $100 \% \mathrm{~N}$ and in control (213.51 to 223.97). Organic sulphur content recorded lower values in the treatments which received sulphur free and imbalance nutrient supply. The extent of increase was minimum in the treatments received imbalanced fertilizer application might be due to the conversion of sulphur from organic form of sulphur to available sulphur through mineralization of $\mathrm{S}$ from soil organic matter, less plant root biomass addition (McLaren and Cameron, 2004). Similarly, declining pattern of organic $S$ with the decrease in organic matter application to soil reported by Kumar et al., (2002).

\section{Residual sulphur}

The data in table 7 indicated the residual fraction of soil $\mathrm{S}$ i.e., the unaccounted $\mathrm{S}$ not extracted by any of the previous sequential extractants. The content and behavior of Res-S with respect to treatment imposition was very similar to that of inorganic sulphur except that the amount of Res-S was higher than HCl-S. This suggests that a portion of $\mathrm{HCl}-\mathrm{S}$ is still retained in the soil.

\section{Total sulphur (T-S)}

The total sulphur content in soil over the years as influenced by long term fertilizer and manure application varied significantly (Table 8). As expected, like other fractions the total sulphur content in soil showed increasing trend over years in all the treatments. However, in $\mathrm{T}_{9}, \mathrm{~T}_{7}$ and $\mathrm{T}_{11}$ treatments, there was decrease in T-S content initially (1991) and then increased gradually over the years and maintained slightly higher over the initial soil T-S content. The extent of increase over 30 years was found maximum in $\mathrm{T}_{10}$ (from 289.40 to $384.04 \mathrm{mg} \mathrm{kg}^{-1}$ ) followed by $\mathrm{T}_{8}$ 
(from 275.30 to $382.82 \mathrm{mg} \mathrm{kg}^{-1}$ ). Continuous use of FYM organic manure and sulphur through SSP helped in buildup of T-S in these treatments. The results were in conformity with the findings of Das et al., (2012), Mazur and Mazur (2015) and Gourav et al., (2018).

Increase in total sulphur content was found to be minimum in treatment $\mathrm{T}_{9}$ (286.33 to 290.11 $\mathrm{mg} \mathrm{kg}^{-1}$ ) which received $\mathrm{S}$ free phosphatic fertilizer (DAP) followed by $\mathrm{T}_{7}$ (287.17 to $296.12 \mathrm{mg} \mathrm{kg}^{-1}$ ) which received only $100 \% \mathrm{~N}$ and control ( 273.78 to $307.30 \mathrm{mg} \mathrm{kg}^{-1}$ ). This might be due to continuous cropping without replenishing sulphur in soil results in release of sulphur from other sources to available pool for crop uptake as there is an equilibrium exists between different fractions of sulphur in soil (Nguyen and Goh, 1990).

The different fractions of sulphur were present in the order of organic > residual> inorganic> water soluble> available form and major form is in organic form. Continuous cropping without replenishment of sulphur and imbalanced fertilizer nutrients leads to depletion of sulphur reserve at faster rate under finger millet and maize cropping system. Integration of inorganic fertilizers with sulphur source and organic manures is essential in maintaining and sustaining the soil fertility with respect to sulphur status.

\section{References}

Anonymous., 1992. Quinquennial Report, 1986 - 1991. All India Coordinated Research Project on Long Term Fertilizer Experiments, Department of Soil Science and Agricultural Chemistry, University of Agricultural Sciences, GKVK, Bengaluru. Anonymous., 2017. Quinquennial Report, 20112016. All India Coordinated Research Project on Long Term Fertilizer Experiments, Department of Soil Science and Agricultural Chemistry, University of Agricultural Sciences, GKVK, Bengaluru.
Azmi, N. Y., Seema and Manish, K., 2018. New technique for sequential fractionation of soil sulphur. Int. J. Curr. Microbiol. App. Sci., pp. 3397-3405.

Bhatnagar, R. K., Bansal, K. N. and Trivedi, S. K., 2003. Distribution of sulphur in some profiles of Shivpuri district of Madhya Pradesh. J. Indian Soc. Soil Sci., 51(1): 74-76.

Chesnin, L. and Yien, C. H., 1951. Turbidimetric determination of available sulphur. J. Soil Sci. Soc. Am. Proc., 15:149-151.

Das, K. N., Basumatari, A. and Borkotoki, B., 2012. Forms of sulphur in some rapeseedgrowing soils of Assam. J. Indian Soc. Soil Sci.,60(1): 13-19.

Gomez, K.A. and Gomez, A. A., 1984. Statistical procedures for agric. Res. $2^{\text {nd }}$ Ed. Jhonwilley and sons, New York.

Gourav, Sankhyan, N. K., Sharma, R. P. and Sharma, G. D., 2018. Vertical distribution of sulfur fractions in a continuously fertilized acid Alfisol under Maize-Wheat Cropping System. Comm. soil sci. plant analysis., 49(8): 923-933.

Hu, Z. Y., Zhao, F. J. and McGath, S. P., 2005. Sulphur fractionation in calcareous soils and bioavailability to plants. Plant Soil, 268(1): 103-109.

Jat, J. R. and Yadav, B. L., 2006. Different forms of sulphur and their relationship with properties of Entisols of Jaipur district (Rajasthan) under mustard cultivation. J. Indian Soc. Soil Sci., 54(2): 208-212.

Kumar, R., Singh, K. P. and Singh. S., 2002. Vertical distribution of sulfur fractions and their relationships among carbon, nitrogen and sulfur in acidic soils of Jharkhand. J. Indian Soc. Soil Sci., 50(3): 502-505.

Mazur, Z. and Mazur, T., 2015. Influence of long-term fertilization on phosphorus, potassium, magnesium, and sulfur content in soil. Polish J. Environ. Studies, 24(1).

McLaren, R. G. and Cameron, K. C., 2004. Soil Sci. 2nd edn., Oxford University Press, Victoria, Australia. 
Nguyen, M. L. and Goh, K. M., 1990. Accumulation of soil sulphur fractions in grazed pastures receiving long-term superphosphate applications. New Zealand Agri. Res., 33(1): 111-128.

Sahoo, A. K., Sah, K. D. and Gupta. S. K. 1998. Sulfur distribution in some mangrove soils of Sunderbans. J. Indian Soc. Soil Sci., 46(1): 138-140.

Scherer, H. W., Welp, G. and Forster, S., 2012. Sulfur fractions in particle-size separates as influenced by long-term application of mineral and organic fertilizers. Plant, Soil Environ., 58(5): 242-248.

Setia, R. K. and Sharma, K. N., 2005. Effect of long-term differential fertilization on depth distribution of forms of sulphur and their relationship with sulphur nutrition of wheat under maize-wheat sequence.J. Indian Soc. Soil Sci., 53(1):91-96.

Sharma, R. K. and Jaggi, R. C., 2001. Relationships of forms and availability indices of sulphur with properties of soils of Kangra, Himachal Pradesh. J. Indian Soc. Soil Sci., 49(4): 698-702.

Sharma, U., Subehia, S. K., Rana, S. S., Sharma, S. K. and Negi, S. C., 2014. Soil sulphur fractions and their relationship with soil properties and rice (Oryza sativa L.) yield under long-term integrated nutrient management in an acid Alfisol. Research on Crops, 15(4).
Shoemaker, H. E., McLean, E. O. and Pratt, P. F., 1961. Buffer methods for determining lime requirement of soils with appreciable amounts of extractable aluminum. Soil Sci. Soc. America J., 25(4): 274-277.

Speir, T. W., Lee, R., Pansier, E. A. and Cairns, A., 1980. A comparison of sulphatase, urease and protease activities on planted and fallow soils. Soil Bio. Biochem.12: 281-291.

Tabatabai, M. A., 1982. Sulfur, In methods of soil analysis Ed. Page, A. L., ASA, Madison, Wisconsin, USA.

Trudinger, P. A., Smith, J. W. and Burns, M. S., 1975. Fractionation of sulfur isotopes by continuous cultures of Desulfovibrio desulfuricans. Canadian. J. Micro., 21(10): 1602-1607.

Williams, C.H. and Steinberg, A., 1959. Soil sulphur fractions as chemical indices of available sulphur in some Australian soils. Australian J. Agric. Res., 10: 340-352.

Xiao H, Li N, Liu C., 2015. Source identification of sulfur in uncultivated surface soils from four Chinese provinces. Pedosphere, 25: 140-149.

\section{How to cite this article:}

Lavanya, K. R., G. G. Kadalli, Siddaram Patil, T. Jayanthi, D. V. Naveen and Channabasavegowda, R. 2019. Sulphur Fractionation Studies in Soils of Long Term Fertilizer Experiment under Finger Millet - Maize Cropping Sequence. Int.J.Curr.Microbiol.App.Sci. 8(09): 1334-1345. doi: https://doi.org/10.20546/ijcmas.2019.809.153 